\title{
Physico-Chemical Parameters of High-Altitude Rivers in the Sagarmatha (Everest) National Park, Nepal
}

\author{
Narayan Prasad Ghimire ${ }^{1 *}$, Pramod Kumar Jha ${ }^{1}$, Gianumberto Caravello ${ }^{2}$ \\ ${ }^{1}$ Central Department of Botany, Tribhuvan University, Kathmandu, Nepal \\ ${ }^{2}$ Department of Environment Health and Hygiene, Padova University, Padova, Italy \\ Email: "nghimire077@gmail.com
}

Received May 18, 2013; revised June 23, 2013; accepted July 3, 2013

Copyright (C) 2013 Narayan Prasad Ghimire et al. This is an open access article distributed under the Creative Commons Attribution License, which permits unrestricted use, distribution, and reproduction in any medium, provided the original work is properly cited.

\begin{abstract}
The aim of this research was to analyse physical and chemical characteristics of high altitude rivers of the Sagarmatha National Park, Khumbu region. The study was conducted for three years from 2008 to 2010 in the elevation $1900 \mathrm{~m}$ to $5300 \mathrm{~m}$ of the park. The study develops a database for monitoring high land rivers of Nepal. The river water quality in general still stands good in terms of standards for drinking water (WHO, Nepal standard) but degradation process has started. Certain changes in water quality parameters in water bodies on the major tourist treks have been recorded, mainly due to anthropogenic activities, particularly tourists and waste disposal. Total nitrogen in water samples is lower than the WHO standard but an increase in the nitrate nitrogen has been recorded comparison between 2008, 2009 and 2010 as well as when compared with earlier reports. Similarly total phosphorous value was also found increased annually as well as earlier reports. It is urgent need to check further degradation of river water quality. The outcomes of this research work would be a useful tool to manage the river water ecosystem in Sagarmatha National Park and Buffer Zone.
\end{abstract}

Keywords: Physico-Chemical Characteristics; High Altitude; Water Quality

\section{Introduction}

Mountains are water towers on earth and surface of livelihood to one-tenth of global population. Mountains are harboring much of the world's endemic biodiversity. Approximately $23 \%$ of earth surface is classified as being mountainous and considering the importance of mountain ecosystems and 32\% of world's protected areas are in elevated land [1]. There are more than 6000 rivers flowing from the Himalayan Mountain to the hills and plains in Nepal with an estimated total length of more than 45,000 $\mathrm{km}$ [2]. Most of these rivers are glacier fed and provide sustained flowing dry season to fulfill the water requirement for the downstream.

The Sagarmatha National Park is facing massive and aggressive anthropogenic pressure that can cause serious environmental consequences to the unique ecosystem. In the last decade, it has been felt that the popular trekking routes have got some adverse environmental effects. Many foreign expeditions that go to the different Himalayan peaks, including Sagarmatha, each year are reported to have left a great deal of garbage in the mountains which

${ }^{*}$ Corresponding author. pollute the environment. Increase in non-biodegradable solid waste such as batteries, bottles and others results in environment pollution. Unmanaged solid waste and open defecation may contaminate drinking water. Trails, campsites and other infra structures are vulnerable to landslide and erosion due to fragile geology of that area which is side effect of tourism.

The pollution problem is now no longer confined to solid waste. Water resources along the trails are being contaminated from improper discharge, human waste and garbage dumping. Sewage and toilet waste can be found piped into nearby streams and rivers [3]. Considering the increasing flow of tourists, the current trend of environmental degradation and ecological significance of SNP, a detail ecological study of the water bodies (rivers) has been planned for research work.

\section{Materials and Methods}

\subsection{Study Sites}

The SNP is located in the southern slope of Sagarmatha (Mt. Everest), lies in the Solukhumbu district of the north eastern region of Nepal and covers $1148 \mathrm{sq} \mathrm{km}$ area. This 
park lies about $140 \mathrm{~km}$ east of Kathmandu. It ranges between $27^{\circ} 30^{\prime} 19^{\prime \prime} \mathrm{N}$ to $27^{\circ} 06^{\prime} 45^{\prime \prime} \mathrm{N}$ latitude to $86^{\circ} 30^{\prime} 53^{\prime \prime} \mathrm{E}$ to $86^{\circ} 99^{\prime} 08^{\prime \prime} \mathrm{E}$ longitude. The park is characterized by rugged topography, altitude of park ranges from $2845 \mathrm{~m}$ at Jorsella to $8848 \mathrm{~m}$ at the top of the Mt. Everest (The World's highest mountain). It comprises three villages Development Committee (VDC) namely Namche, Khumjung and Chaurikharka. The mountains of Sagarmatha National Park are geologically young and broken up by deep gorges and glacial valleys. Tourism is major source of economy of Khumbu region and many local residents still depend upon agro-pastoral activities.

The Sagarmatha National Park (SNP) located in the District of Solukhumbu, Nepal, is privileged with the Mount Everest, the highest peak of the world and many other peaks over 7000 m. The Sagarmatha National Park (SNP) was established in 1976 and declared as a world Natural Heritage Site in 1979. It is a popular eco-touristic destination for international community. Since the first ascent of Everest in 1953, around half a million trekkers (national \& international) visited the SNP. The number of tourists in the Khumbu region was 20 in 1964, which rose to peak number 32,123 in 2009 and 32,084 in 2010. In addition to international trekkers, a large number of people visit the SNP as porter and guide. On one side, there is economic gain through tourism in the Khumbu region; on the other it has produced some environmental concern [3]. The area is inhabited mainly by Sherpa, followed by Tamang, Rai ethnic groups.

The Sagarmatha National Park covers the catchment basins of the Dudh Kosi, the Bhote Kosi and Imja Khola rivers which drains the slope of Sagarmatha and other peaks, also covers lobuche river originated from the Gokyo Lakes included in Ramsar site in 2007 (Figure 1).

\subsection{Sample Collection}

Water samples from 51 locations were collected and analyzed in three consecutive years 2008, 2009 and 2010. The criteria of selection of sampling points were based on vicinity of tourist trail located on the banks of river water bodies and sources of major river system.

\subsection{Field Measurement}

Physical parameters: temperature, $\mathrm{pH}$, conductivity, TDS were measured and chemical parameters nitrogen and phosphorous were analyzed in different years (2008, $2009,2010)$ to record the physical and chemical characters of rivers on different sampling points to understand the status and annual changes in aquatic ecosystem of rivers water system in Sagarmatha National Park and Buffer Zone.

\subsection{Sample Preservation and Lab Analysis}

Water samples were collected from the water bodies in

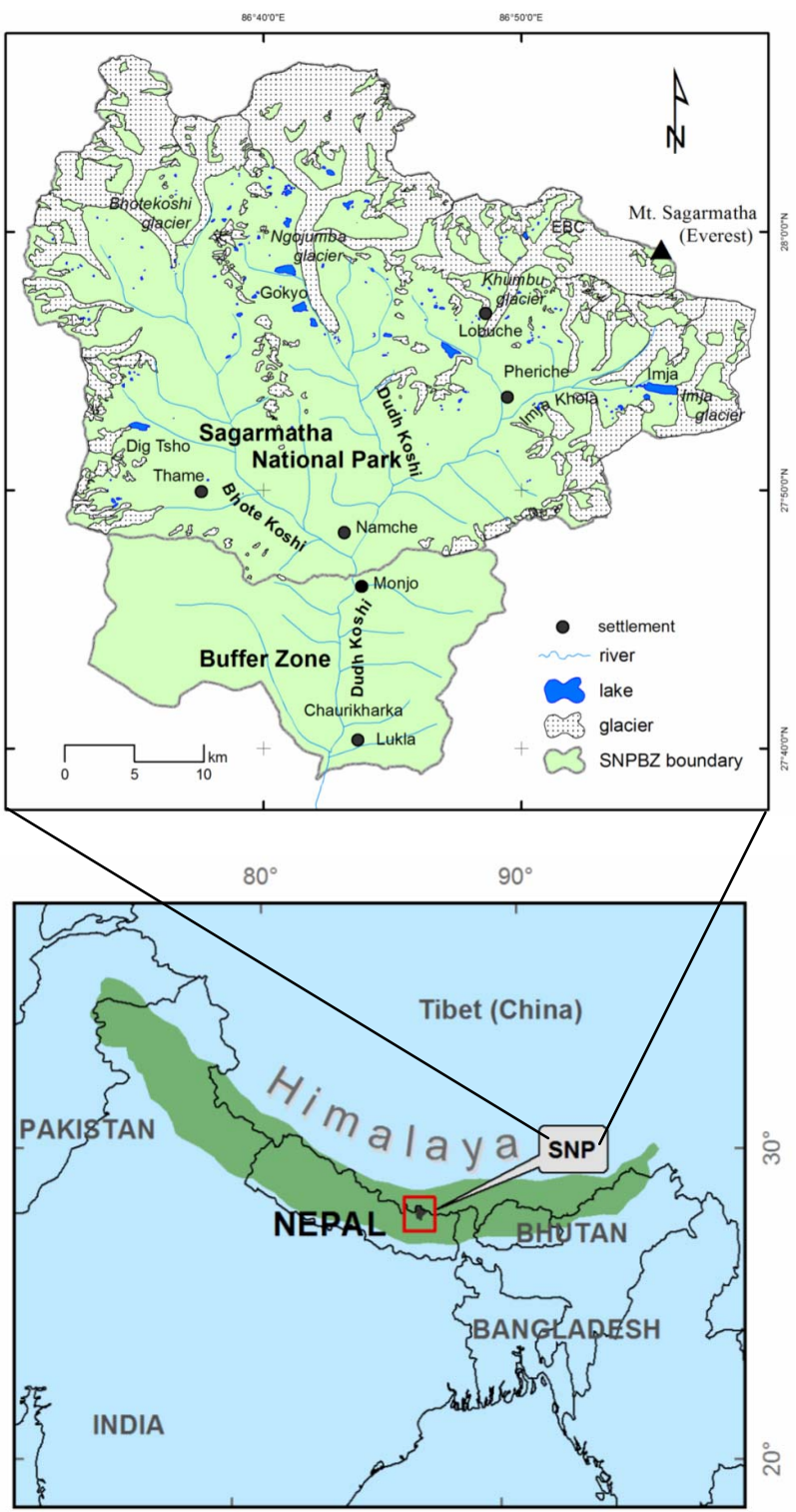

Figure 1. Location of Sagarmatha National Park in south Asia and position of rivers in SNP.

acid rinsed polythene bottle of capacity $125 \mathrm{ml}$. Three drops of concentrated nitric acid were used to adjust the $\mathrm{pH}$ of the samples below 2 (acidic medium) to preserve it. The samples were brought to Kathmandu and analyzed in Ecology lab, Central Department of Botany, Tribhuvan University, Kathmandu. Nitrogen and Phosphorous contents in lake water samples were measured by colorimetric method by making the standard curve method following Trivedy and Goel [4].

\section{Result and Discussion}

\subsection{Temperature}

Main rivers are Dudhkoshi, Bhotekoshi, Imja khola and Lobuche river. Seventeen different sampling plots were 
made for analysis of water bodies to analyse the seasonal variation in temperature. The average temperatures were noted between range $8^{\circ} \mathrm{C}-13^{\circ} \mathrm{C}$ (Tables 1 and 2). But, in 2010, some points showed higher than the average value; temperature of Lobuche river near meeting point of Chola pass $\left(17^{\circ} \mathrm{C}\right)$, Bhotekoshi below a bridge between Thamo and Thame was $15^{\circ} \mathrm{C}$, Dudhkoshi at Phakding $15^{\circ} \mathrm{C}$. Average minimum temperature was recorded in Ngozumpa Glacier $\left(8.2^{\circ} \mathrm{C}\right)$ may be due to high altitude
(4600 m) as well as glacier melt water (Tables 1 and 2). So, it showed the minimum temperature in all season, 2008, 2009 and 2010. Sharma et al. [5] also recorded the temperature of surface water of Gokyo $3^{\text {rd }}$ lake was $8^{\circ} \mathrm{C}$ and $2^{\text {nd }}$ lake, was $7^{\circ} \mathrm{C}$ for the surface water. Glacier retreat in the Everest region was found very rapidly (5.5 $8.7 \mathrm{~m} / \mathrm{annum})$ which accelerated (5.56 - $9.1 \mathrm{~m} / \mathrm{annum})$ during the 1997-2001 [6] which may be the Climate change [7]. So, there was found the increasing trend of

Table 1. Description of the sampling site.

\begin{tabular}{|c|c|c|c|c|}
\hline S.N & Name of site & Lat. & Long. & Alt. (m) \\
\hline A7 & Dudh Koshi at Phakding & 27.73983 & 86.71077 & 2587 \\
\hline A8 & Dudh koshi above Jorselle & 27.7825 & 86.72218 & 2777 \\
\hline A10 & Dudh koshi at Punki Tenga & 27.83152 & 86.74657 & 3298 \\
\hline A12 & Dudh koshi at Panboche and Deboche & 27.84985 & 86.78017 & 3760 \\
\hline A13 & Dudhkoshi between Pheriche and Panboche & 27.88681 & 86.81836 & 4170 \\
\hline A15 & Lobuche khola from side of Pheriche & 27.93848 & 86.80726 & 4290 \\
\hline A16 & Imja khola below Denboche village & 27.88023 & 86.81877 & 4165 \\
\hline A17 & Imja just upper Denboche village & 27.89652 & 86.83938 & 4383 \\
\hline A19 & Lobuche near meeting of Chola pass & 27.93705 & 86.80658 & 4843 \\
\hline A20 & Lobuche khola near Lobuche & 27.94707 & 86.80658 & 4919 \\
\hline A21 & Snow melt from EBC & 28.00387 & 86.85597 & 5331 \\
\hline A32 & Ngozumpa glacier & 27.93088 & 86.70822 & 4656 \\
\hline A36 & Dudhkoshi at Phorse Tenga & 27.85207 & 86.74365 & 3604 \\
\hline $\mathrm{A} 40$ & Bhotekoshi above Thame & 27.84258 & 86.6445 & 3805 \\
\hline A43 & Bhotekoshi between Thamo and Thame & NA & NA & 3700 \\
\hline A44 & Bhotekoshi near Thamo & 27.81933 & 86.67817 & 3410 \\
\hline A62 & Dudh koshi below Surke & 27.6664 & 86.70925 & 1941 \\
\hline
\end{tabular}

Table 2. Characteristics of river water at seventeen sampling stations in Sagarmatha National Park.

\begin{tabular}{|c|c|c|c|c|c|c|c|c|c|c|c|c|c|c|c|c|c|c|}
\hline \multirow{2}{*}{ S.N } & \multicolumn{3}{|c|}{ Temp $\left({ }^{\circ} \mathrm{C}\right)$} & \multicolumn{3}{|c|}{$\mathrm{pH}$} & \multicolumn{3}{|c|}{ TDS } & \multicolumn{3}{|c|}{ Conductivity (mS) } & \multicolumn{3}{|c|}{$\mathrm{TN}-\mathrm{NO}_{3}(\mathrm{mg} / \mathrm{l})$} & \multicolumn{3}{|c|}{$\mathrm{TP}-\mathrm{PO}_{4}(\mathrm{mg} / \mathrm{l})$} \\
\hline & 2008 & 2009 & 2010 & 08 & 09 & 010 & 08 & 09 & 010 & 08 & 09 & 010 & 08 & 09 & 010 & 08 & 09 & 010 \\
\hline A7 & 9.5 & 12.5 & 14.0 & 7.2 & 7.1 & 7.1 & 0.02 & 0 & 0.01 & 0.03 & 0.01 & 0.02 & 0.89 & 0.77 & 0.67 & 0.23 & 0.18 & 0.30 \\
\hline A8 & 12.5 & 12.5 & 12.0 & 7.3 & 6.8 & 6.3 & 0.02 & 0.01 & 0.01 & 0.03 & 0.02 & 0.02 & 0.32 & 0.37 & 1.83 & 0.03 & 0.14 & 0.13 \\
\hline A10 & 8.6 & 11.0 & 9.2 & 7.3 & 7.0 & 6.7 & 0.02 & 0.01 & 0.01 & 0.03 & 0.02 & 0.02 & 1.21 & 0.89 & 0.00 & 0.15 & 0.32 & 0.53 \\
\hline A12 & 13.7 & 11.3 & 10.0 & 7.3 & 7.2 & 7.5 & 0.02 & 0.04 & 0.02 & 0.03 & 0.07 & 0.03 & 0.80 & 0.72 & 0.00 & 0.19 & 0.00 & 0.19 \\
\hline A13 & 8.5 & 10.8 & 9.5 & 7.3 & 7.2 & 7.0 & 0.02 & 0.00 & 0.01 & 0.03 & 0.02 & 0.02 & 0.47 & 0.28 & 0.93 & 0.14 & 0.23 & 0.34 \\
\hline A15 & 9.5 & 10.3 & 7.2 & 7.7 & 6.8 & 8.1 & 0.02 & 0.02 & 0.02 & 0.03 & 0.04 & 0.03 & 0.71 & 1.75 & 2.20 & 0.09 & 0.12 & 0.29 \\
\hline A16 & 9.3 & 10.4 & 10.0 & 7.4 & 6.9 & 7.0 & 0.02 & 0.01 & 0.01 & 0.03 & 0.02 & 0.02 & 0.50 & 0.43 & 2.20 & 0.14 & 0.24 & 0.24 \\
\hline A17 & 8.5 & 10.1 & 10.0 & 7.6 & 6.7 & 7.2 & 0.02 & 0.01 & 0.02 & 0.02 & 0.02 & 0.03 & 0.27 & 0.84 & 3.6 & 0.65 & 0.65 & 0.26 \\
\hline A19 & 11.5 & 10.5 & 17.0 & 7.6 & 6.8 & 7.0 & 0.01 & 0.01 & 0.04 & 0.02 & 0.02 & 0.07 & 0.12 & 0.31 & 1.01 & 0.09 & 0.44 & 1.01 \\
\hline A20 & 10.5 & 10.3 & 11.0 & 7.2 & 6.7 & 8.0 & 0.03 & 0.02 & 0.04 & 0.04 & 0.04 & 0.06 & 0.27 & 1.53 & 0.73 & 0.65 & 0.46 & 0.48 \\
\hline A21 & 10.0 & 10.2 & 7.8 & 7.4 & 6.9 & 7.5 & 0.00 & 0.00 & 0.00 & 0.01 & 0.00 & 0.01 & 0.77 & 0.44 & 1.60 & 0.07 & 0.12 & 1.44 \\
\hline A32 & 6.7 & 9.5 & 8.4 & 8.5 & 6.9 & 6.6 & 0.02 & 0.03 & 0.02 & 0.03 & 0.04 & 0.04 & 0.68 & 0.69 & 0.00 & 0.11 & 0.12 & 0.22 \\
\hline A36 & 8.8 & 10.6 & 8.7 & 7.7 & 6.8 & 6.2 & 0.02 & 0.02 & 0.02 & 0.03 & 0.04 & 0.03 & 0.63 & 0.69 & 2.17 & 0.29 & 0.29 & 0.49 \\
\hline A 40 & 14.0 & 9.5 & 13.0 & 7.4 & 7.0 & 6.4 & 0.02 & 0.01 & 0.01 & 0.03 & 0.02 & 0.02 & 1.01 & 0.79 & 1.78 & 0.74 & 0.11 & 0.63 \\
\hline A43 & 11.5 & 10.5 & 15.0 & 7.4 & 7.3 & 7.2 & 0.01 & 0.01 & 0.01 & 0.02 & 0.01 & 0.01 & 1.08 & 1.03 & 2.03 & 0.48 & 0.24 & 0.12 \\
\hline A44 & 12.5 & 8.5 & 14.0 & 7.6 & 7.1 & 6.9 & 0.01 & 0.00 & 0.01 & 0.02 & 0.01 & 0.02 & 0.97 & 0.71 & 1.07 & 0.32 & 0.30 & 1.38 \\
\hline A62 & 12.0 & 12.0 & 12.0 & 7.2 & 7.2 & 7.2 & 0.02 & 0.02 & 0.02 & 0.03 & 0.03 & 0.03 & 0.76 & 0.76 & 0.76 & 0.24 & 0.24 & 0.24 \\
\hline
\end{tabular}


temperature of the water bodies of SNPBZ (Figure 2).

\section{2. $\mathbf{p H}$}

The $\mathrm{pH}$ values of water varied from 6.5 to 8.0 indicating slightly alkaline nature of water (Figure 3 ). The values of water were observed within the permissive limit $\mathrm{pH}(7$ - 8.5) prescribed for the drinking water (WHO, 1971) [8]. In average, higher values (7.3 and 7.33) were noted by Lobuche river near Lobuche settlement and Ngozumpa glacier where as lowest (6.8) by Dudhkoshi above Jorselle (Tables 1 and 2). But some variation showed occasionally in different sampling points by different year. Ngozumpa glacier in 2008 was noted 8.5, Dudhkoshi at Phorse Tenga (6.2) in 2010 (Tables 1 and 2). Renold et al. [9] found 6.5 to 8.7 in the surface water of upper Khumbu region. Present studies in all types of water also showed the similar trend as previous studies. For $\mathrm{pH}$ point view, the all water bodies are still good for drinking as well as other purpose. But $\mathrm{pH}$ values were found significantly decreasing (Figure 3).

\subsection{TDS}

The average value of the TDS in River water bodies showed the range between 0.007 and 0.03 (Tables 1 and 2; Figure 4). Some points showed the occasionally higher value in 2010, Lobuche khola near Lobuche (0.04), Lobuche khola near meeting of Chola pass (0.04) (Tables 1 and 2). Similarly lower limits of water bodies of TDS are shown in different year by different samplings points. Bhotekoshi near thamo showed 0.01 in 2008 and 2010. Bhotekoshi below the bridge between thamo and thamo, Dhdhkoshi at Phakding, Dhdhkoshi above Jorselle, Dudhkoshi above Phunki Tenga showed 0.01. No record

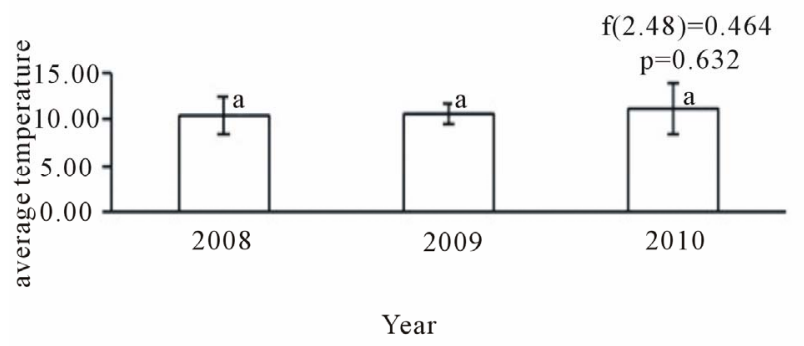

Figure 2. Average of water temperature of river in 2008, 2009 and 2010.

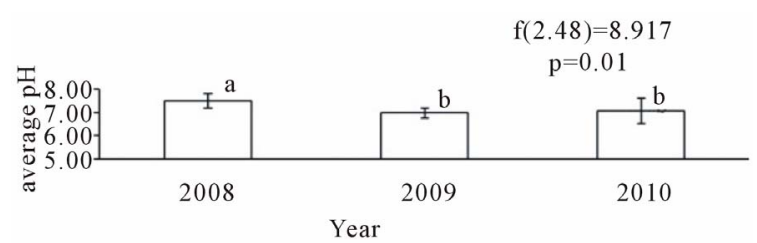

Figure 3. Average pH of river water in 2008, 2009 and 2010.

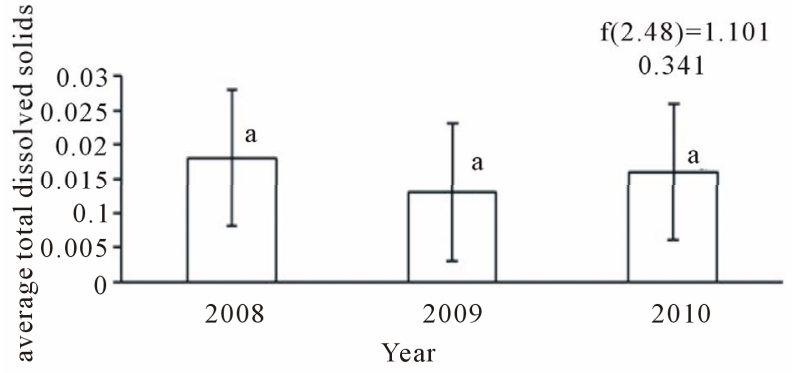

Figure 4. Average total dissolved solids in river water in 2008, 2009 and 2010.

of TDS was noted in the glacier river of Mt. Everest Base Camp in 2008, 2009 and 2010 (Table 2).

\subsection{Conductivity}

The water characteristics of river in term of conductivity were recorded between 0.01 and 0.05 (Tables 1 and 2; Figure 5). Major sampling points showed the similar value (0.02) in all season except few places. Some points were found slightly higher value in 2008, Dhdhkoshi between Panboche and Deboche (0.04), Lobuche near chola pass (0.04), Lobuche khola near Lobuche settlement (0.04) value were recorded. In second year (2009), Dudhkoshi between Panboche and Deboche (0.07), Lobuche river near Lobuche (0.04), Dudhkoshi at Phunki Tenga (0.04) were recorded. In 2010 (final year), Lobuche near chola pass (0.07), Lobuche khola near Lobuche (0.06) gener- ally recorded higher value (Tables $\mathbf{1}$ and 2). Nearly same result found by earlier researcher (0.008 $0.067 \mathrm{~s} / \mathrm{cm}$ by Lami et al. [10] for High altitude water bodies of Khumbu valley, 0.011 to $0.51 \mathrm{~s} / \mathrm{cm}$ by Antoninetti et al. [11] for Khumbu water bodies. 0.019 to 0.057 $\mathrm{s} / \mathrm{cm}$ in the streams of upper khumbu valley by Renold et al. [9], from the conductivity data; the water ecology is still undisturbed as well as pollution free (Figure 5).

\section{Chemical Properties}

\subsection{Total Nitrate-Nitrogen $\left(\mathrm{TN}-\mathrm{NO}_{3}\right)$}

The average values were analyzed between the ranged 0.46 - $1.57 \mathrm{mg} / \mathrm{l}$ (Tables 1 and 2). The higher value was recorded in different samplings points: Lobuche khola from the side of Pheriche (1.55 mg/l), Imja khola near Denboche village $(1.57 \mathrm{mg} / \mathrm{l})$, Dudhkoshi at phorse tenga $(1.16 \mathrm{mg} / \mathrm{l})$, Bhotekoshi below a bridge between thamo and thame $(1.38 \mathrm{mg} / \mathrm{l})$, Bhotekoshi avove thame (1.19 $\mathrm{mg} / \mathrm{l})$. Lower values were recorded; ( $0.48 \mathrm{mg} / \mathrm{l})$ Lobuche near meeting of chola pass, $0.46 \mathrm{mg} / \mathrm{l}$ by Ngozumpa glacier, $(0.51 \mathrm{mg} / \mathrm{l})$ by Dudhkoshi at panboche and Deboche, (0.56 mg/l) by Dudhkoshi between Pheriche and Panboche (Tables 1 and 2).

Similarly, some points showed the higher value than the average value. In first year (i.e. 2008), Dudhkosh at 


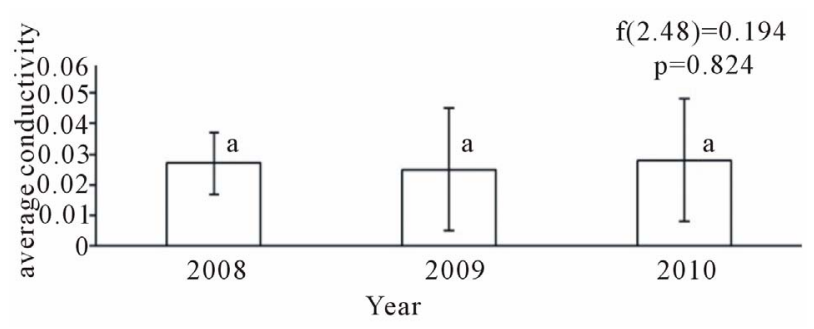

Figure 5. Annual conductivity of river water in 2008, 2009 and 2010.

Table 3. Average annual mean comparison between 2008, 2009 and 2010 in the river.

\begin{tabular}{cccc}
\hline Parameters & $\mathbf{2 0 0 8}$ & $\mathbf{2 0 0 9}$ & $\mathbf{2 0 1 0}$ \\
\hline Temp $\left({ }^{\circ} \mathrm{C}\right)$ & $10.447 \pm 2.051255$ & $10.618 \pm 1.041174$ & $11.106 \pm 2.750334$ \\
$\mathrm{pH}$ & $7.479 \pm 0.311245$ & $6.968 \pm 0.195433$ & $7.064 \pm 0.53591$ \\
$\begin{array}{c}\text { Conductivity } \\
\text { (mS) }\end{array}$ & $0.027 \pm 0.00686$ & $0.025 \pm 0.016627$ & $0.028 \pm 0.015904$ \\
$\begin{array}{c}\mathrm{TDS} \\
(\mathrm{ppt})\end{array}$ & $0.018 \pm 0.006642$ & $0.013 \pm 0.011048$ & $0.016 \pm 0.010572$ \\
$\begin{array}{c}\mathrm{TN}-\mathrm{NO} \\
\text { (mg/lit) }\end{array}$ & $0.674 \pm 0.312811$ & $0.765 \pm 0.393702$ & $1.328 \pm 0.97291$ \\
$\begin{array}{c}\mathrm{TP}-\mathrm{PO}_{4} \\
(\mathrm{mg} / \mathrm{lit})\end{array}$ & $0.271 \pm 0.223855$ & $0.247 \pm 0.158026$ & $0.488 \pm 0.410191$ \\
\hline
\end{tabular}

P.T (1.21 mg/l), Bhotekoshi above thame $1.01 \mathrm{mg} / \mathrm{l}$. In 2009, Lobuche Khola near Pheriche $(1.75 \mathrm{mg} / \mathrm{l})$, Lobuche khola near Lobuche $(1.5 \mathrm{mg} / \mathrm{l})$. In the final year (2010), some points showed the higher value: Imja khola (3.6 mg/l), Lobuche khola near Pheriche (2.2 mg/l), Dhdhkoshi at Phunki Tenga (2.17 mg/l), Bhotekoshi below bridge between Thamo and Thame was $(2.03 \mathrm{mg} / \mathrm{l})$. The value of 2010 showed the increased trend than the previous year. Ngozumpa glacier showed $0.37 \mathrm{mg} / \mathrm{l}$ previous where as present average $\mathrm{TN}$ as nitrate was recorded 1.05 $\mathrm{mg} / \mathrm{l}(0.71 \mathrm{mg} / \mathrm{l}$ in 2008, $2.17 \mathrm{mg} / \mathrm{l}$ in 2010) (Tables 1 and 2). Lobuche khola at Lobuche as well as Pheriche also ex- hibited significantly higher than the earlier mentioned. It was recorded 0.17 to $0.237 \mathrm{mg} / \mathrm{l}$ earlier but $1.41 \mathrm{mg} / \mathrm{l}$ in Lobuche khola at Pheriche and $0.75 \mathrm{mg} / \mathrm{l}$ at Lobuche which is 4 - 5 times greater as the previous recorded. Some earlier researcher also mentioned the atmospheric nitrogen deposition rate significantly affect $\mathrm{TN}-\mathrm{NO}_{3}$ value for the water bodies $(0.3 \mathrm{~kg} / \mathrm{ha} /$ year by Tartari et al. [12]. Rivers were found running near agricultural land, settlement, garbage pit, septic tank (toilet), direct discharge waste towards nearby springs and rivers (i.e. Phakding, Lobuche, Pheriche, Tamang spring Lukla, Namche spring etc.).

Renold et al. [9] reported the range in khumbu region for NO3-N, 0.01 to $0.69 \mathrm{mg} / \mathrm{l}$ for surface water and 0.15 to $0.17 \mathrm{mg} / \mathrm{l}$ for spring's water, 0.03 to $0.21 \mathrm{mg} / \mathrm{l}$ for glacier melt water of khumbu region and 0.04 to $0.29 \mathrm{mg} / \mathrm{l}$ for stream of Upper khumbu valley. Comparatively TN-
$\mathrm{NO}_{3}$ data were found to be significantly increased from 2008, 2009 and 2010 (Table 3 and Figure 6).

\subsection{Total Phosphate-Phosphorous (TP-PO}

The average values were recorded between $0.10-0.67$ $\mathrm{mg} / \mathrm{l}$. The minimum value showed by Dudhkoshi above jorselle $(0.10 \mathrm{mg} / \mathrm{l})$, Dudhkoshi between panboche and Deboche $(0.13 \mathrm{mg} / \mathrm{l})$, where as the higher values were Bhotekoshi near thamo $(0.67 \mathrm{mg} / \mathrm{l})$, lobuche khola at lobuche $(0.53 \mathrm{mg} / \mathrm{l})$, snow melt river at Base camp (0.54 $\mathrm{mg} / \mathrm{l})$ (Tables 1 and 2).

In the first year, values were recorded between 0.03 $0.74 \mathrm{mg} / \mathrm{l}$ (Table 2). Lowest value was recorded by Dudhkoshi above jorselle $(0.03 \mathrm{mg} / \mathrm{l})$, where as the maximum was showed by Lobuche khola near lobuche $(0.65 \mathrm{mg} / \mathrm{l})$. $2010>2009>2008>$ previous report trends were observed in average value among 2008, 2009 and 2010 (Figure 7). But occasionally, some points in 2009 and 2010, some points showed more than $1 \mathrm{mg} / \mathrm{l}$. In 2010, snow melt water from EBC was $1.44 \mathrm{mg} / \mathrm{l}$, Lobuche metting of chola pass was $1.01 \mathrm{mg} / \mathrm{l}$, Bhotekoshi near thamo $1.38 \mathrm{mg} / \mathrm{l}$. In 2009, all the points showed the range between 0.00 - $0.65 \mathrm{mg} / \mathrm{l}$. Value was not detected amount (negligible) in Dudhkoshi at Panboche and Deboche. Highest value was recorded by Imja khola near Denboche village $0.65 \mathrm{mg} / \mathrm{l}, 0.46 \mathrm{mg} / \mathrm{l}$ by Lobuche khola near Lobuche (Tables 1 and 2). Lami et al. [10] analyzed water chemistry and concluded that phosphorous contained lower than $0.005 \mathrm{mg} / \mathrm{l}$ in more than $50 \%$ samples where as the present average phosphorous as phosphate value was found $0.345 \mathrm{mg} / \mathrm{l}$. Antoninetti et al. [11] recorded

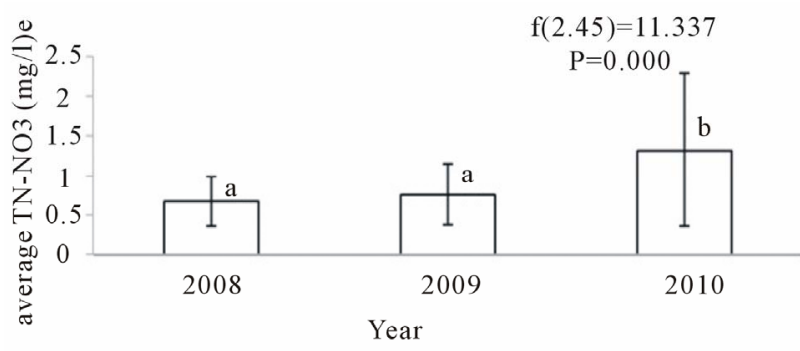

Figure 6. Average nitrate-nitrogen of river water in 2008, 2009 and 2010.

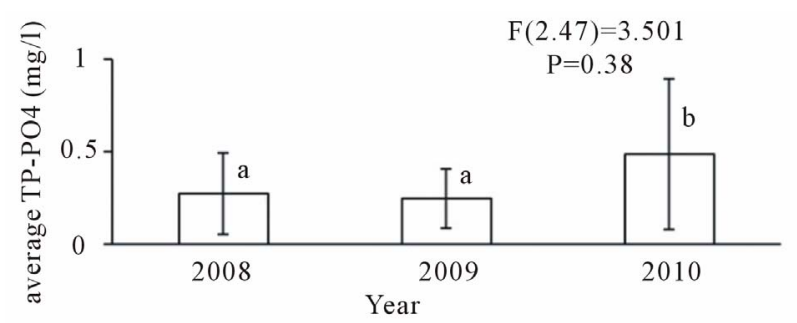

Figure 7. Average phosphorous-phosphate of river water in 2008, 2009 and 2010. 
between 0.002 and $0.011 \mathrm{mg} / \mathrm{l}$ in water of khumbu Himal which was less value than that obtained 2007. This value was found higher in 2010. So, comparatively there is a trend of increasing of the value of phosphorous in water bodies (Table 3 and Figure 7).

\section{Conclusions}

The river water quality in general still stands good in terms of standard for drinking water (WHO, Nepal Standard) but degradation process has started. Certain changes in water quality parameters in water bodies on the major tourist treks have been recorded, mainly due to anthropogenic activities, particularly tourists and waste disposal.

The present findings reveal that pollutants presence in the water bodies of the Khumbu region is increasing; the level of the pollutants in general has not crossed the Nepalese or WHO standards except at few places. The toilet condition in the Khumbu region is not satisfactory, as leakage of excreta from most of the toilets is observed. Improvement in the toilet condition can prevent the pollutants from sources to the water bodies. No construction of septic tanks (e.g. at Somare, Pheriche), leakage from septic tanks (e.g. at Gorakhshep), no construction of toilets (e.g. at Thamo), and high permeability of the septic tanks are the common problems. The present findings reveal that pollutants presence in the water bodies of the Khumbu region is increasing (previous report $>2008>$ 2009 > 2010); the level of the pollutants in general has not crossed the Nepalese or WHO standards except at few places.

Changing the value of $\mathrm{pH}$, significantly increased value of $\mathrm{TN}-\mathrm{NO}_{3}, \mathrm{TP}-\mathrm{PO}_{4}$, all indicating the river water bodies of SNPBZ are going to degrade in quality. Sources of pollutants are: 1) human waste (toilet) disposed to the water bodies, 2) different type of litter employed in the agriculture field, and 3) solid waste, human wastes (excreta) and solid waste disposal is mainly by tourists.

Non-scientific solid waste management, open defecation and poor condition of septic tanks, and direct disposal of toilet waste to water courses or on the exposed surface, are major sources of surface water pollution. High solid waste generation due to high tourism flow, no proper management practice of solid waste, open defecation, starting the use of chemical fertilizer, construction of garbage pit near to the water coarse are found the root causes for water pollution. Improvement in the conditions of toilets and septic tanks can prevent the pollutants from sources to the water bodies.

\section{Acknowledgements}

Thanks to HKKH Partnership Project for financial support to conduct this research, and to department of Na- tional Park and Wildlife Conservation and Sagarmatha National Park for permission to work in Sagarmatha National Park and Buffer Zone.

\section{REFERENCES}

[1] L. S. Hamilton, "Conserving Mountain Biodiversity in Protected Areas,” In: C. Korner and E. M. Spehn, Eds., Mountain Biodiversity: A Global Assessment, New York and London, 2002.

[2] CBS, "Statistical Year Book of Nepal," CBS, Kathmandu, 1995.

[3] G. U. Carovello, A.M. Boselli, P. Bertollo and A. Baroni, "Assessing Ecosystem Health: An Analysis of Tourism Related Change and Impact in Khumbu Valley, Nepal," Ecoprint, Vol. 14, 2007, pp. 45-64.

[4] R. K. Trivedy and P. K. Goel, "Chemical and Biological Methods for Water Pollution Studies,” Environment Publication, Karad, 1986.

[5] C. M. Sharma, S. Sharma, S. Gurung, I. Juttner, R. M. Bajracharya and N. Shrestha Pradhan, "Ecological Studies within the Gokyo Wetlands, Sagarmatha National Park, Nepal,” In: P. K. Jha and I. Khanal, Eds., Contemporary Research in Sagarmatha (Mt. Everest) Region, Nepal: An Anthology, Nepal Academy of Science and Technology, Kathmandu, 2010, pp. 139-154.

[6] J. Ren, D. Qin, S. Kang, S. Hou, J. Pu and Z. Jing, “Glacier Variations and Climate Warming and Drying in the Central Himalayas,” Chinese Science Bulletin, Vol. 49, 2004, pp. 65-69.

[7] J. D. Ives, “Global Warming: A Threat to Mount Everest?” Mountain Research and Development, Vol. 25, No. 4, 2005, pp. 391-394. doi:10.1659/0276-4741(2005)025[0391:GWTTME]2.0.C $\mathrm{O} ; 2$

[8] WHO, “Guidelines for Drinking Water Quality [Electronic Resource]: Third Edition, Incorporating the First and Second Addenda, Volume 1, Recommendations," World Health Organization, Geneva, 2008, p. 668.

[9] B. Reynolds, A. Jenkins, P. J. Chapman and J. Wilkinson, "Stream Hydrochemistry of the Khumbu, Annapurna and Lantang Regions of Nepal,” In: Top of the World Enviromental Research: Mount Everest-Himalayan-Ecosystem, Backhuys Publishers, Leinden, 1998, pp.123-140.

[10] A. Lami, G. A. Tartari, S. Musazzi, P. Guilizzoni, A. Marchetto, M. Manca, A. Boggero, A. M. Nocentini, G. Morbito, G. Tartari, L. Luzzella, R. Bertoni and C. Callieri, "High Altitude Lakes: Limnology and Paleolimnology,” In: Mountains Witnesses of Global Changes, Elsevier Publication, 2007, pp. 155-170.

[11] M. Antoninetti, M. Pepe, G. Iabichino, C. De Vito and G. Tartari, "Environmental Information System of KhumbuHimal Areas. In: R. Baudo, G. Tartari and M. Munawar, Eds., Top of the World Environmental Research: Mount Everest-Himalayan Ecosystem, Backhuys Publishers, Leiden, 1998, pp. 263-284.

[12] G. A. Tartari, G. Tartari and R. Mosello, "Water Chemistry of High Altitude Lakes in the Khumbu and Imja Kola 
Valleys (Nepalese Himalayas),” In: A. Lami and G. Giussani, Eds., Limnology of High Altitude Lakes in the Mt
Everest Region (Nepal)," Memorie dell'lstituto Italiano di Idroln'olog'ia, Vol. 57, 1998, pp. 51-76. 